\title{
Truncation as a novel form of variation of the p50 gene in Mycoplasma hominis
}

\author{
Birgit Henrich, Klaudia Lang, Annette Kitzerow, Colin MacKenzie \\ and Ulrich Hadding
}

Institute for Medical

Microbiology and

Virology, Moorenstrasse 5,

Heinrich-Heine-University,

40225 Duesseldorf,

Germany

\author{
Author for correspondence: Birgit Henrich. Tel: +49 211811 5206. Fax: +492118115323. \\ e-mail: Birgit.Henrich@uni-duesseldorf.de
}

\begin{abstract}
A characteristic feature of the mycoplasmas is the presence of variable surface proteins which may play an important role in the adaptation of the cell-wallless organisms to their host environments. In addition, this antigen variation may be an important pathogenic property of the organism. The ubiquity of the gene encoding P50, an adhesin of Mycoplasma hominis FBG, and its transcription were analysed in different isolates of $M$. hominis. The p50 gene was present in all isolates tested. Based on Southern blot analysis and sequencing of the gene, the isolates could be classified into one of three distinct groups. Within two groups specific truncations of the p50 gene occurred. The reduction of the gene size was confirmed in Northern blot analysis of representative isolates from each group, with a decrease in transcript length from $1.6 \mathrm{~kb}$ in group G-1 down to $0.76 \mathrm{~kb}$ in group G-3. In addition to truncation, a coincidental duplication of some gene segments was detected. This work has provided evidence for the genetic basis of a further variation in the $M$. hominis P50 adhesin.
\end{abstract}

Keywords: Mycoplasma hominis, adhesin, antigen variation, gene diversity, mutagenesis

\section{INTRODUCTION}

Mycoplasma hominis is a prokaryote belonging to the class of cell-wall-less Mollicutes and has been associated with human urogenital infections, postpartum fever, septic arthritis and pneumonia (Krause \& TaylorRobinson, 1992; Mardh et al., 1983). At present, it remains unresolved which factors lead to virulence; however, as a first step of invasion, adherence to the epithelium must occur. As the cell wall is absent, this is most likely mediated by structures in the mycoplasma cell membrane. A number of surface-exposed proteins, often characterized by antigenic variation, have been described in M. hominis (Christiansen, 1992; Henrich $e t$ al., 1996; Olson et al., 1991a; Wise et al., 1992; Zhang $\&$ Wise, 1996). This phenomenon of antigenic variation is widespread among the Mollicutes and may contribute to evasion of the host defences (Christiansen et al., 1990; Olson et al., 1991b; Rosengarten \& Wise, 1990, 1991).

Clones of the arthritogenic M. hominis isolate 1620

The EMBL accession numbers for the $\mathrm{p} 50$ gene sequences of the isolate nos $2,3,12-16$ and 22 reported in this paper are AJ005053-AJ005060, respectively. show antigenic variation in the $v a a$ (variable-adherenceassociated) genes, resulting in the expression of $\mathrm{Vaa}$ peptides with up to four repeats of a 121 aa motif. Homology searches strongly suggest that P50, an adhesin molecule of $M$. hominis FBG (Feldmann et al., 1992; Henrich et al., 1993), is a Vaa antigen variant expressed in this strain. Three-quarters of the P50 adhesin consists of the repetitive domains A, B and C, which can be differentiated by mAbs (Henrich et al., 1996).

We have reported on the function of P50 in mediating cytadhesion (Henrich et al., 1993); however, the ubiquity of P50 in $M$. hominis has remained unclear as $\mathrm{mAbs}$ which were specific for P50 in strain FBG reacted with only $42 \%(\mathrm{mAb} \mathrm{BA} 10)$ and $6 \%(\mathrm{mAb} \mathrm{BG} 2)$ of $M$. bominis isolates tested (Feldmann et al., 1992). To determine whether the isolates which did not react with the $\mathrm{mAb}$ contain and express the gene encoding P50, we analysed these isolates at the DNA and mRNA level.

\section{METHODS}

Plasmids. We constructed the plasmids which were used for Southern blotting by cloning a NsiI-HindIII fragment (p50-I), a HindIII fragment (p50-II) and a HindIII-XbaI fragment 


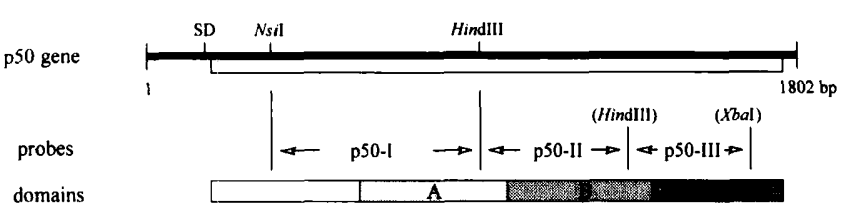

Fig. 1. $p 50$ gene and subclones used as hybridization probes. A map of the constructs carrying regions of the p50 gene is shown. Cleavage sites for the enzymes Nsil, HindlII and Xbal as well as the Shine-Dalgarno sequence (SD) are indicated. Restriction sites which were generated in the subclones by point mutations are shown in parentheses. The ORF is represented by the open box. The positions of the P50 coding regions for domains $A, B$ and $C$ are shown relative to the location of the hybridization probes $\mathrm{p} 50-\mathrm{I}$, - II and - III used in this study.

(p50-III) of the p50 gene of M. hominis FBG into the plasmid pTRBHis as published recently (Henrich et al., 1996). The positions of p50-I, p50-II and p50-III within the p50 gene are shown in Fig. 1. These p50 fragments were used as hybridization probes, after either restriction endonuclease digestion and fragment isolation (probe $\mathrm{p} 50-\mathrm{I}$ ) or amplification by PCR (probes p50-II and p50-III). The oligonucleotides used in PCR were synthesized with a solid carrier on an Applied Biosystems $381 \mathrm{~A}$ machine according to the phosphoamidite method (Caruthers, 1982) : p50-II sense oligonucleotide, 5' AAA AGC TTG GTC AAA AGA ATT AGC 3'; p50-II antisense oligonucleotide, 5' TTC AAG CTT CTT GTA CTT TTG CCC ATT 3'; p50-III sense oligonucleotide, 5' AAG AAG CTT GGA AAA ATG AAT TAG CAG 3'; p50-III antisense oligonucleotide, $5^{\prime}$ TTT TCT AGA ACC ATG TGG TAT TC $3^{\prime}$. PCR was carried out in a $100 \mu$ reaction mixture with $0 \cdot 1 \mu \mathrm{mol}$ genomic FBG DNA, $125 \mu \mathrm{mol}$ NTPs, 50 pmol each primer and $0.5 \mathrm{U}$ Taq polymerase for 35 cycles [1 min at $94^{\circ} \mathrm{C}, 2.5 \mathrm{~min}$ at $56^{\circ} \mathrm{C}, 1.5 \mathrm{~min}\left(+1 \mathrm{~s}\right.$ per cycle) at $74^{\circ} \mathrm{C}$ ] in PCR buffer obtained from Perkin-Elmer Cetus or AGS. As a positive control, part of the tuf gene of M. hominis (bp 1541158 of the coding region) was amplified in a PCR reaction with $1 \mathrm{ng}$ DNA of the plasmid pMHEL2 (Lüneberg et al., 1991) and the primer pair tuf sense oligonucleotide, $5^{\prime}$ TAA GGT ACC AG(G/A/T) AGA AAA AGC AC(T/G) (A/T)G $3^{\prime}$, and $t u f$ antisense oligonucleotide, $5^{\prime}$ AGT GGT A(G/C)C ACC TTC A(G/C)G A(A/T)T (C/A)GA GA 3', using the same reagent concentrations as above for 35 cycles $[1 \mathrm{~min}$ at $94^{\circ} \mathrm{C}, 1 \mathrm{~min}$ at $46^{\circ} \mathrm{C}, 2 \mathrm{~min}\left(+5 \mathrm{~s}\right.$ per cycle) at $72^{\circ} \mathrm{C}$ ]. The plasmids pT7T3-19U and pUC-19 were used for cloning genomic p50 DNA of different $M$. hominis isolates and were propagated in Escherichia coli DH5 $\alpha \mathrm{F}^{\prime}$ (Gibco-BRL).

DNA manipulations. Plasmid construction, restriction endonuclease digestion, ligation, preparation and transformation of competent $E$. coli cells, agarose gel electrophoresis and fragment purification were carried out by standard procedures (Sambrook et al., 1989) or by following the instructions of commercial suppliers.

Mycoplasmal growth. Clinical isolates of M. hominis which had been obtained from routine diagnostic specimens (mostly from the vagina, rarely from cervix or vulva) were grown to mid-exponential phase in a conventional mycoplasma broth medium as described previously (Henrich et al., 1993). Isolates were identified to a species level biochemically by arginine metabolism and serologically using $M$. hominis-specific mAbs and polyclonal serum obtained from the National Collection of Type Cultures (NCTC), London, UK. These isolates were taken from a collection of 126 strains previously published (Feldmann et al., 1992). Mycoplasma cells were harvested by centrifugation $\left(15000 \mathrm{~g}, 30 \mathrm{~min}, 4^{\circ} \mathrm{C}\right)$.

Preparation of genomic DNA and RNA. For Southern blot analysis and subsequent cloning, the genomic DNA of different $M$. hominis isolates was isolated by the use of the QIAamp Tissue kit (Qiagen) following the tissue protocol with the single modification of a 10 -fold higher preparation volume (e.g. $5 \times 10^{8}$ mycoplasma cells per $1.8 \mathrm{ml} \mathrm{ATL} \mathrm{ex-}$ traction buffer). For Northern blot analysis the mycoplasma RNA was prepared using the RNeasy-kit (Qiagen). The concentrations of DNA and RNA were estimated spectrophotometrically. From $100 \mathrm{ml}$ broth culture of $M$. bominis isolates, a mean of $40-80 \mu \mathrm{g}$ genomic DNA and $50-100 \mu \mathrm{g}$ RNA was purified.

Southern blot analysis. Genomic DNA of $M$. hominis was digested to completion with the restriction endonuclease HindIII $\left[2 \mathrm{U}(\mu \mathrm{g} \mathrm{DNA})^{-1}\right]$ and separated on $0.8 \%$ agarose gels (10 $\mu$ g DNA per lane), transferred to Hybond-N membranes (Amersham) and hybridized with DNA fragments which were labelled with digoxigenin-conjugated dUTP by hexanucleotide primed second strand synthesis according to the supplier's protocol (Boehringer Mannheim) or nick translation (Southern, 1975). After hybridization, the filters were washed three times at room temperature and three times at $37^{\circ} \mathrm{C}$, each for $5 \mathrm{~min}$ in $2 \times \mathrm{SSC} / 0.1 \%$ SDS followed by digoxigenin detection in a chemiluminescence reaction (Boehringer Mannheim).

To strip the DNA, the filters were washed for $45 \mathrm{~min}$ in $2 \times$ $\mathrm{SSC} / 50 \mathrm{mM} \mathrm{Na}-\mathrm{EDTA}$, $\mathrm{pH} 8.0$, at $85^{\circ} \mathrm{C}, 15 \mathrm{~min}$ in $2 \times$ $\mathrm{SSC} / 0.1 \%$ SDS at room temperature, and $45 \mathrm{~min}$ in $0.1 \%$ $\mathrm{SDS} / 0 \cdot 2 \mathrm{M} \mathrm{NaOH}$ at $37^{\circ} \mathrm{C}$. The same blot was used for each of the four different hybridization reactions performed.

Northern blot analysis. RNA of the different $M$. hominis isolates ( $30 \mu \mathrm{g}$ RNA per isolate) was separated on a denaturing $1 \%(\mathrm{w} / \mathrm{v})$ agarose-formaldehyde gel (Sambrook et al., 1989) and transferred to a positive-charged nylon membrane (Boehringer). After cross-linking with UV light $\left(0.6 \mathrm{~J} \mathrm{~cm}^{-2}\right)$ the membranes were prehybridized in Church buffer $(0.25 \mathrm{M}$ $\mathrm{Na}_{2} \mathrm{HPO}_{4}, \mathrm{pH} 7.4 ; 1 \mathrm{mM} \mathrm{Na}-\mathrm{EDTA} ; 7 \%$, w/v, SDS) for $10 \mathrm{~min}$ at $65^{\circ} \mathrm{C}$ and then hybridized to the digoxigeninlabelled p50-I probe (12 ng DNA ml-1) overnight at $65^{\circ} \mathrm{C}$ in Church buffer. The hybridization steps as well as the following stringent washes were performed at $65^{\circ} \mathrm{C}$ in $40 \mathrm{mM} \mathrm{Na}$ $\mathrm{HPO}_{4} / 1 \%(\mathrm{w} / \mathrm{v})$ SDS. Hybridization patterns were detected using the DIG Detection kit (Boehringer Mannheim) according to the manufacturer's instructions, modified by depleting $\mathrm{MgCl}_{2}$ from the buffers, which minimized background staining.

Sequence analysis. The p50 gene sequences were determined on an $\mathrm{ABI} 373 \mathrm{~A}$ machine using the dideoxy chain-termination reaction (Sanger et al., 1977) on genomic DNA after cloning (see Plasmids section). Alignment of the p50 genes and the construction of a p50-domain-specific phylogenetic tree were done with the computer program MegAlign of the software program package Lasergene (DNASTAR). The membership of the analysed p50 regions to the respective segments encoding domains $\mathrm{A}, \mathrm{B}$ or $\mathrm{C}$ was estimated by using the neighbour-joining method (Saito \& Nei, 1987) from the program section CLUSTAL $v$ of MegAlign (Higgins \& Sharp, 1989). 


\section{RESULTS}

\section{Ubiquity of p50 gene sequences in $M$. hominis}

To elucidate whether the $M$. hominis FBG adhesin molecule P50, previously shown to be species specific (Feldmann et al., 1992), was also present in all $M$. hominis strains, we analysed the p50 gene in 25 different clinical isolates, the type strain PG21 and strain FBG.

Three different regions of the p50 gene of $M$. hominis strain FBG (p50-I, 519 bp; p50-II, 363 bp; and p50-III, $300 \mathrm{bp}$ ) were used as hybridization probes for HindIIIdigested genomic DNA. As shown in Fig. 1, each of the p50 probes encodes the main part of one of the three P50 protein domains A (p50-I), B (p50-II) or C (p50-III). These three domains have a $67 \cdot 1 \%$ homology to one another with respect to isofunctional amino acids, and $28 \%$ of the residues are identical (Henrich et al., 1996).

As shown by the hybridization pattern in Fig. 2, the region encoding the $\mathrm{N}$-terminal part of the P50 adhesin molecule (p50-I) was present in all of the 27 isolates. The p50-I region was localized on a $6.5 \mathrm{~kb}$ HindIII fragment in 17 isolates and on the remainder of the isolates on fragments of 7.5 or $9 \mathrm{~kb}$. Only one isolate, lane 15 , showed a hybridization signal on a fragment larger than $9 \mathrm{~kb}$, and one isolate, lane 13, showed two hybridization signals of 6.5 and $0.5 \mathrm{~kb}$.

In contrast, domain B sequences detected by probe $\mathrm{p} 50$ II were only found in 14 of 27 isolates. As can be seen in the Southern blot of probe p50-III in Fig. 2, lanes 1-12 showed the same hybridization pattern as that of probe p50-II. This suggests that both regions p50-II and p50-III were present on the same HindIII fragment. The lengths of the HindIII fragments detected by probes p50-II and -III ranged from 0.5 to $3 \mathrm{~kb}$. When a probe specific for the tuf gene of M. hominis PG21 (Lüneberg et al., 1991) was used to probe the membrane, fragments containing the tuf gene were detected (Fig. 2), confirming that the assay was sufficiently sensitive to detect a single copy locus.

\section{p50-I}

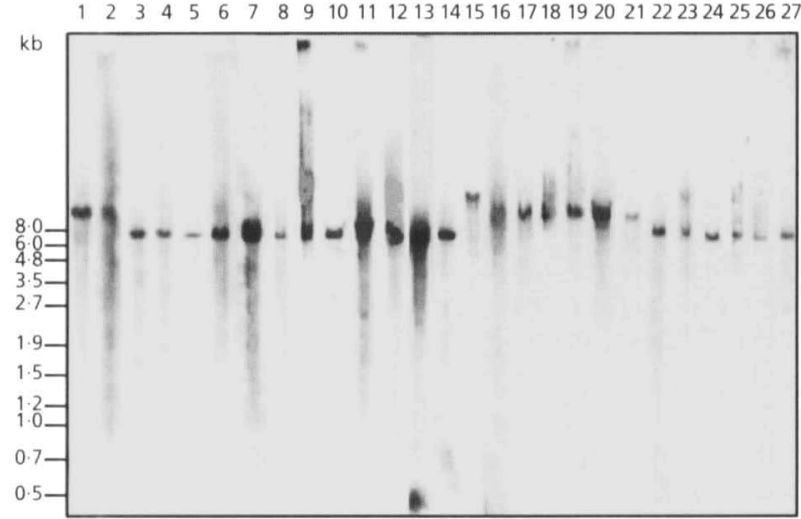

p50-III

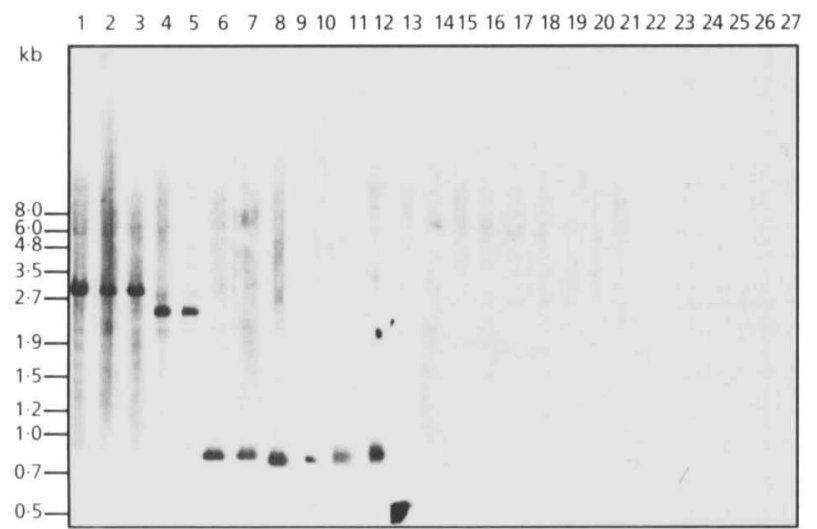

p50-II

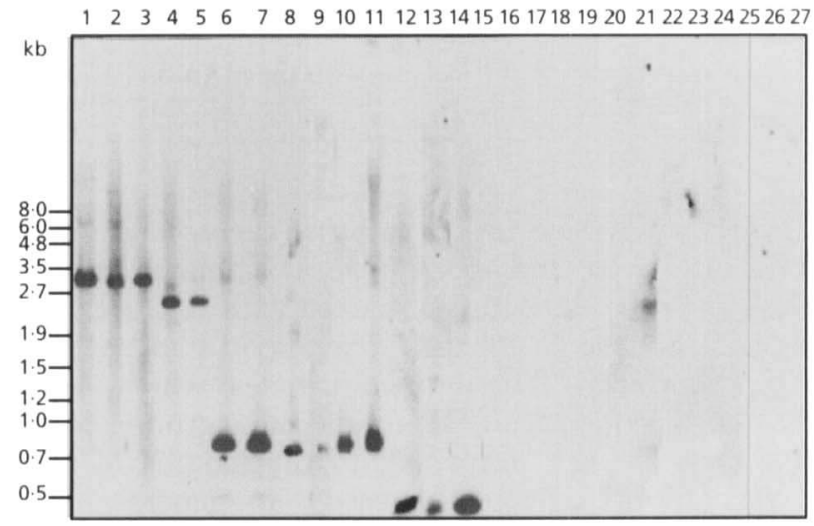

tuf

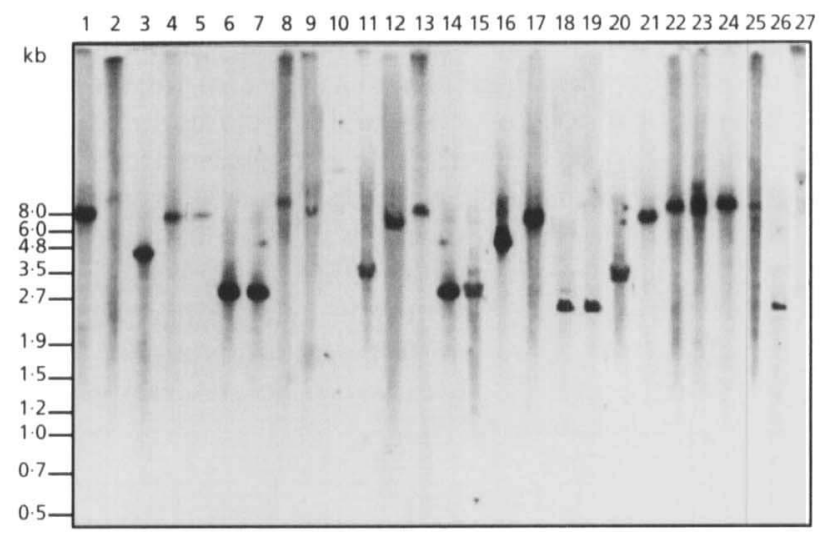

Fig. 2. Southern blot analysis of the p50 genes in $M$. hominis isolates. Genomic DNA (10 $\mu$ g per isolate) of 27 different $M$. hominis isolates was digested with HindIII and afterwards separated in a $0.8 \%(w / v)$ agarose gel. The DNA was transferred to Hybond-N (Amersham) and the same filter was hybridized four times with digoxigenin-labelled DNA of probes p50-I, p50-II, p50-III (parts of the p50 gene of $M$. hominis FBG; see Fig. 1) and tuf (part of the tuf gene of $M$. hominis PG21). The lane numbers correspond to the isolate numbers given in Table 1 . The size of each hybridizing fragment was calculated from the genomic DNA marker (DNA-Marker VII, digoxigenin-labelled; Boehringer Mannheim). 
Table 1. P50 groups of the $M$. hominis isolates

\begin{tabular}{|c|c|c|c|c|c|c|}
\hline \multirow[t]{2}{*}{ Group* } & \multirow[t]{2}{*}{$\begin{array}{c}\text { Isolate } \\
\text { no. }\end{array}$} & \multicolumn{3}{|c|}{$\begin{array}{l}\text { HindIII fragments } \neq \\
\text { detected by: }\end{array}$} & \multicolumn{2}{|c|}{$\begin{array}{c}\text { Immunostained } \$ \\
\text { with } \mathbf{m A b}:\end{array}$} \\
\hline & & p50-I & p50-II & p50-III & BA10 & BG2 \\
\hline G-1.1 & $1-2$ & $9 \cdot 0$ & 3.0 & $3 \cdot 0$ & + & + \\
\hline G-1.2 & 3 & $6 \cdot 5$ & $3 \cdot 0$ & $3 \cdot 0$ & - & - \\
\hline G-1.3 & $4-5$ & $6 \cdot 5$ & $2 \cdot 5$ & $2 \cdot 5$ & + & + \\
\hline G-1.4 & $6-11$ & 6.5 & 0.7 & 0.7 & + & - \\
\hline G-1.5 & 12 & $6 \cdot 5$ & 0.5 & 0.5 & + & - \\
\hline G-2.1 & 13 & $6.5 / 0.5$ & 0.5 & - & - & - \\
\hline G-2.2 & 14 & 6.5 & 0.5 & - & + & - \\
\hline G-3.1 & 15 & $>9.0$ & - & - & - & - \\
\hline $\mathrm{G}-3.2$ & $16-20$ & $9 \cdot 0$ & - & - & - & - \\
\hline G-3.3 & 21 & $7 \cdot 5$ & - & - & - & - \\
\hline$G-3.4$ & $22-27$ & $6 \cdot 5$ & - & - & - & - \\
\hline
\end{tabular}

* The membership of a distinct group (G-1.1 to G-3.4) results from the distinct hybridization patterns in Southern blot analysis (Fig. 2) leading to the proposed grouping of M. hominis isolates from G-1.1 to G-3.4.

† The numbering of the different $M$. hominis isolates (1-27) corresponds to the respective lanes in Fig. 2.

$¥$ The lengths of the genomic HindIII fragments which hybridized to the respective probe p50-I, -II or -III of isolate FBG (no. 4) are indicated in kb.

$\$+$, Positive reactivity of the isolates with the mAb BA10 and BG2; - , no reactivity.

On the basis of hybridization patterns, the isolates were divided into three major groups. As summarized in Table 1, isolates of group G-1 reacted with all three p50 gene probes, those of group G-2 with p50-I and p50-II only and group G-3 contained isolates which only reacted with probe $\mathrm{p} 50$-I. Within the three groups, subgroups were defined according to the lengths of the genomic DNA fragments detected. In general, this grouping was supported by a P50-specific immunostaining pattern obtained with the mAbs BA10 and BG2 (Feldmann et al., 1992) as documented in Table 1. Characterization of the P50 adhesin in 126 clinical isolates of $M$. hominis revealed that $42 \%$ of the strains were immunostained by mAb BA10 (Feldmann et al., 1992) and, as can be seen in Table 1 , these isolates were only found in groups G-1 and G-2. The $6 \%$ of isolates that were immunostained by $\mathrm{mAb}$ BG2 all belonged to group G-1. The Southern blot data described above confirmed the presence of the p50 gene. However, as isolates of group 3 were not immunostained, the question of whether all $M$. hominis isolates expressed P50 remained unanswered.

\section{P50-related transcripts in $M$. hominis}

The P50 expression at an mRNA level was analysed in representative isolates from the major groups G-1, G-2 and G-3. As Southern blot analysis revealed that all isolates carried p50-I gene sequences, the p50-I probe was used for hybridization in Northern blots. Fig. 3 shows the transcript lengths of representatives of each of the three major groups. Isolates of group G-1, represented by strain FBG (lane 1) and type strain PG21 (lane 2 ), had the largest mRNA of about $1.6 \mathrm{~kb}$. Isolate no. 14 of group G-2 (lane 3) had a transcript length of about $1.2 \mathrm{~kb}$ and isolates 16 (lane 4) and 22 (lane 5) of group G3 had transcripts of about 1.2 and $0.76 \mathrm{~kb}$, respectively. A total of 14 isolates were examined and for every isolate tested one $\mathrm{p} 50$-specific mRNA was detected with a length corresponding to that expected for a member of the respective group as seen in Fig. 3. Thus the lengths of the mRNAs were consistent with the finding that $\mathrm{p} 50$ genes are truncated in groups G-2 and G-3.

\section{Sequencing of different isolates demonstrates the p50 gene truncation}

To provide evidence that the $\mathrm{p} 50$-specific hybridization patterns and mRNA lengths detected in each proposed group were due to different sizes of truncations of the p50 gene, we cloned and sequenced p50-gene-spanning genomic fragments of $M$. hominis isolates representing groups G-1, G-2 and G-3. All sequences were then clustered according to their homology with the p50 gene of isolate FBG (no. 4). The accuracy of the use of defined segments encoding the respective $\mathrm{P} 50$ domains $\mathrm{A}, \mathrm{B}$ or $\mathrm{C}$ was then proven by the construction of a p50-domainspecific phylogenetic tree which supported the grouping (data not shown). The resulting $\mathrm{p} 50$ gene constructs of the $M$. bominis isolates are shown schematically in 


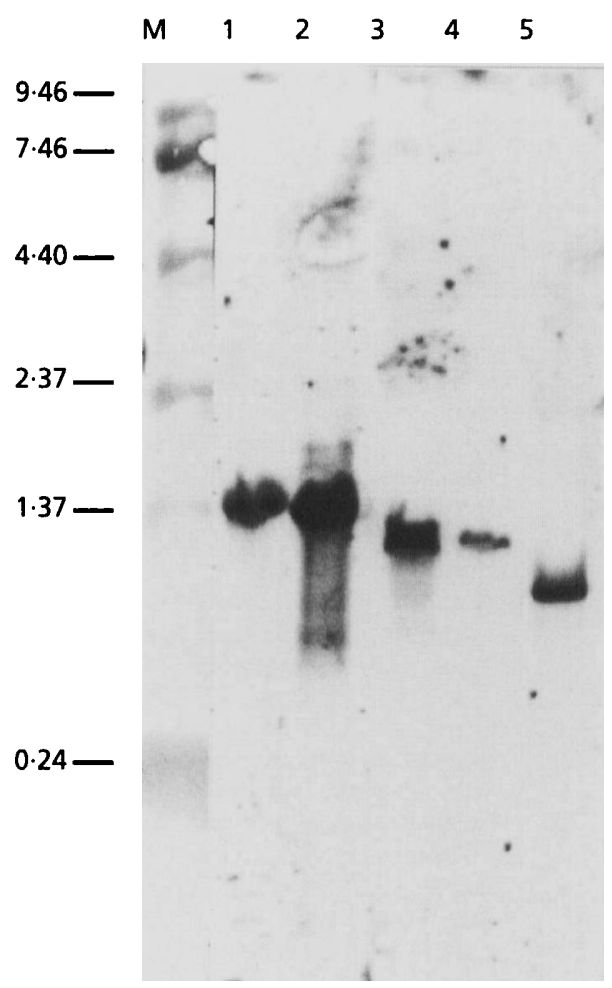

Fig. 3. Northern blot analysis of p50 gene transcripts. The p50-Ispecific digoxigenin-labelled probe (Fig. 1) was hybridized to $30 \mu \mathrm{g}$ total RNA of isolates 4, FBG (lane 1), and 6, PG21 (lane 2), representatives of group 1 ; isolate 14 (lane 3 ), representative of group 2; and isolates 16 and 22 (lanes 4 and 5, respectively), representatives of group 3 . Lane $M$ is an RNA ladder (0.24-9.46 kb; Gibco-BRL) stained with methylene blue.

Fig. 4; the common feature of all p50 genes was the maintenance of the $\mathrm{N}$-terminal part-O-encoding segment, and this explained the hybridization of the p50-I probe to every M. hominis isolate analysed (Fig. 2).

Isolate nos 2, 3 and 12, all members of group G-1, showed the same composition of the p 50 gene as FBG (no. 4), each also containing the regions encoding the domains A, B and C. The homology of the p50 gene between these isolates ranged from 94 to $99 \%$, which supported their classification in the same group, G-1. The deduced polypeptide sequence of p50 genes in isolate nos 2 and 12 corresponded to the P50 adhesin of strain FBG, whereas an insertion of thymidine in position 728 of the gene in isolate no. 3 reduced the ORF to $777 \mathrm{nt}$, which is indicated by an arrow in Fig. 4, no. 3 .

The $\mathrm{p} 50$ gene of isolate no. 13, a member of group G-2, had an ORF of $1422 \mathrm{bp}$. Comparison of the gene sequence with sequences in the EMBL database revealed a $98.5 \%$ homology to the vaa-2 gene of the arthritogenic M. hominis strain 1620 (Zhang \& Wise, 1996), including a duplication of the region encoding domain $\mathrm{A}$ and simultaneous deletion of the segment encoding domain B (Fig. 4, no. 13). That the region encoding domain A2 in isolate no. 13 shared $68 \%$ homology to domain $\mathrm{B}$ of isolate FBG (no. 4) is in good agreement with the findings in Southern blot analysis where both the p50-I probe and the p50-II probe hybridized to the $0.5 \mathrm{~kb}$ fragment of isolate no. 13 encoding domain A2 (see Fig. 2). The failure to detect domain $C$ of isolate no. 13 with probe p50-III in Southern blot analysis can be explained by the reduced homology (only $33 \%$ ) between probe p50-III and the respective genomic HindIII fragment of isolate no. 13.

Sequencing of the p50 gene in isolate no. 14 , a member of group G-2 which failed to react with probe p50-III, revealed that the p50-III HindIII fragment, encoding part of domain B and most of domain C, was absent, showing that truncation can occur across domains and does not always occur within each domain. Interestingly, the conserved $35 \mathrm{bp} \mathrm{C-terminal} \mathrm{end} \mathrm{was} \mathrm{still} \mathrm{present,} \mathrm{an}$ observation already published by Zhang \& Wise (1996) for other vaa genes.

Isolate nos 15, 16 and 22, members of group G-3, all shared the common feature of a large deletion within the p50 gene, spanning the entire domain A region and most of domain $\mathrm{B}$. What remained of the $\mathrm{p} 50$ genes consisted of the conserved region $\mathrm{O}$, a $61 \mathrm{bp}$ region encoding a truncated $\mathrm{B}^{\prime}$ domain and domain $\mathrm{C}$ with the same $24 \mathrm{bp}$ deletion as isolate no. 13 of group G-2. As explained for isolate no. 13, the absence of hybridization signals in Southern blot analysis (Fig. 2) was attributable to the reduced homology of probe p50-III with the respective genomic HindIII fragments of these three isolates.

A deletion of $1 \mathrm{bp}$ in the conserved region $\mathrm{O}$ of isolate no. 15 led to the generation of a premature stop codon in position 135 of the gene. Isolate no. 16 was characterized by a duplication of the domain $\mathrm{C}$ segment leading to an entire ORF of 936 bp which corresponded well with the transcript length of $1.2 \mathrm{~kb}$ detected in Northern blot analysis (Fig. 3, lane 4). This p50 gene variant is the first one described with a 35 bp region (indicated as an asterisk in Fig. 4) within an ORF, whereas in all other p50 or vaa genes so far analysed this region represents the conserved C-terminus (Zhang \& Wise, 1996). The length $(711 \mathrm{bp})$ of the ORF of the p50 gene in isolate no. 22 correlated well with the transcript length of $0.76 \mathrm{~kb}$ found in Northern blot analysis (Fig. 3, lane 5).

\section{DISCUSSION}

In this study, we have demonstrated that p50 gene sequences exist in all $M$. hominis isolates tested. The Southern and Northern blot data presented here also support the finding of Zhang $\&$ Wise (1996) that p50 occurs as a single copy gene in $M$. bominis. The region encoding the $\mathrm{N}$-terminus of $\mathrm{p} 50$ (p50-I) was detected in every isolate tested, whereas the sequence encoding the middle section ( $\mathrm{p} 50-\mathrm{II}$ ) was found in only 14 of 27 isolates and the region encoding the C-terminus of p50 in 12 of 27 isolates, leading to a separation of isolates into three main groups, G-1, G-2 and G-3. The isolates of group G-1, which contain the p50 gene segments encoding all three domains, had transcripts of 1.4 $1.6 \mathrm{~kb}$, isolates of group $\mathrm{G}-2$, which did not hybridize 


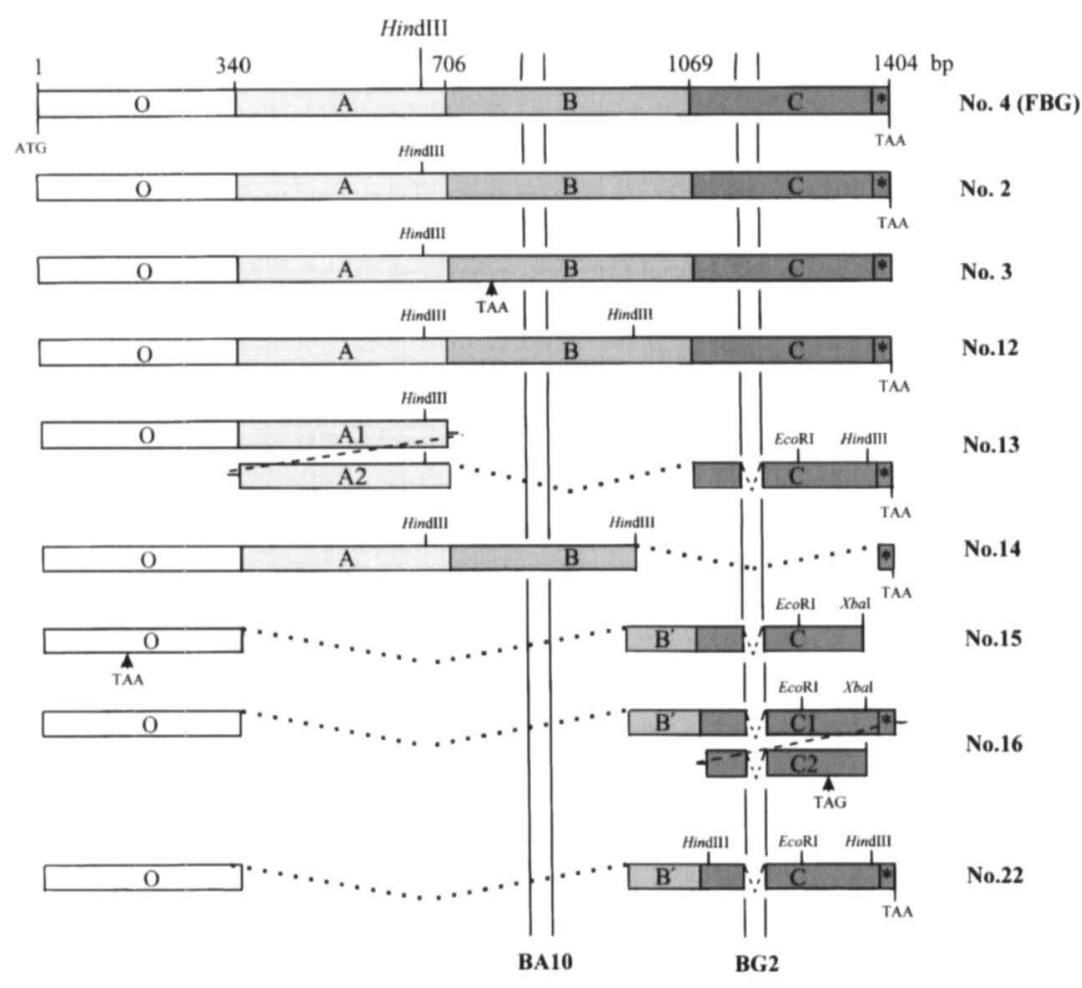

Fig. 4. Structural features of the p50 genes in isolates from groups 1,2 and 3 . The p50 genes were sequenced in the isolates 2,3 , 12-16 and 22 and analysed using the computer program MegAlign (DNASTAR). Regions of the gene in each isolate were assigned on the basis of their homology to domains $A, B$ and $C$ in the p50 gene of isolate FBG (isolate 4). The highly homologous $35 \mathrm{bp}$ C-terminus (Zhang \& Wise, 1996) was separately analysed and is marked by an asterisk. Deletions within the truncated p50 genes of the isolates 13-16 and 22 are indicated by dotted lines, and stop codons are marked by arrows. The vertical areas drawn in represent the epitope-encoding regions of mAb BA10 (bp 831-872) and of mAb BG2 (bp 1152-1184) as recently published (Henrich et al., 1996). with the probe p50-III, had transcripts of $1.2-1 \cdot 4 \mathrm{~kb}$, and isolates of group G-3, which only hybridized with probe p50-I, had a further decrease in transcript length, to as small as $0.76 \mathrm{~kb}$. To determine the molecular basis for these findings, representatives of each group were further analysed by sequencing the respective p 50 genes. Sequence analysis confirmed the proposed truncation of the p50 gene in isolates of groups G-2 and G-3.

Besides the deletion of gene regions of different sizes, insertion (isolate no. 3) or deletion (isolate no. 15) of a single nucleotide was detected leading to frameshifting and subsequent truncation of the respective ORFs. Zhang \& Wise (1997) published the localization of a reversible frameshift mutation in the p50 gene homologue, $v a a$, in clonal populations of $M$. hominis strain 1620 and identified a distinct poly-A tract as a frameshift mutator element. Insertion or deletion of one adenosine resulted in either a complete Vaa ORF or an in-frame TAG stop codon immediately downstream from the poly-A tract. Although no adenosine-related mutator element was detected in the neighbourhood of the site of point mutation in isolates 3 and 15 in this study, another mechanism may exist for a reversible mutation. As the remainder of the p 50 gene sequence in isolate 3 remained unaffected, reversion of the described insertion would reconstitute expression of the $50 \mathrm{kDa}$ adhesin.

Despite these considerations, this is the first description of the p50 adhesin gene being the template of an apparently irreversible truncation process. Truncations were focused on domain-encoding regions, but not restricted to the respective segment boundaries, whereas the $\mathrm{p} 50$ gene region $\mathrm{O}$ was preserved in every isolate.
The consequence of a size-reduced adhesin variant in $M$. bominis with regard to the cytadherence was analysed by Zhang \& Wise (1997). The M. hominis $\mathrm{Vaa}^{-}$variant carrying the truncated Vaa ORF had markedly reduced adherence to HeLa cells. The authors suggested that varying adherence may generate and maintain functional diversity in $M$. hominis during infections.

It should be noted that the high degree of homology between the p 50 gene of isolate 13 and vaa-2 from the arthritogenic $M$. hominis isolate 1620 shows that both are variations of the same gene. Since isolate 13 originated from the urogenital tract (as do most isolates in this paper) whereas isolate 1620 originated from a joint (Olson et al., 1991a), it would appear that at least for the vaa-2-containing isolate, tissue-specific pathogenicity may not be mediated by this $\mathrm{p} 50$ variant.

The P50 molecule may not only play an important role in the adherence of the organism to host cells but may also, through mutation and variation, allow evasion of the host immune system. As described before only $42 \%$ of all isolates were immunostained with $\mathrm{mAb}$ BA10 and $6 \%$ with $\mathrm{mAb} \mathrm{BG} 2$. Reactivity with the $\mathrm{mAb}$ was found mainly in isolates of group 1 , which possess the coding sequence for the entire $50 \mathrm{kDa}$ adhesin. The failure of isolate 3 to immunostain was explained by the presence of a point mutation in the region encoding the $\mathrm{N}$ terminal part of domain B which led to a premature stop codon. An analysis of the deduced P50 polypeptide in isolate 12 revealed a low homology in the region of the BG2 epitope to that in strain FBG, resulting in loss of BG2 binding. Furthermore, in all analysed isolates of groups 2 and 3 the BG2 epitope was found to be deleted 
in an otherwise expressed domain C. This, in combination with the truncation of larger sequences containing the BA10 epitope, explained the failure of both $\mathrm{mAbs}$ to detect the adhesin in these isolates. In addition, reactivity of $\mathrm{P} 50$-specific polyclonal serum with only $65 \%$ of the isolates (unpublished data), in the presence of an ORF and a p50 transcript, provides further evidence that antigenic variation of the P50 molecule may be an important mechanism in evasion of host defence. Cytadherence studies using recombinant peptides which represented different regions of the P50 protein of strain FBG showed that the domains A, B and $\mathrm{C}$ and the $\mathrm{N}$-terminal region $\mathrm{O}$ all had the ability to adhere (unpublished data). Thus the loss of major antigenic regions provides the organism with the advantage of host defence evasion without necessarily leading to a reduction in cytadherence.

Sequencing of the p50 genes in isolates 13 and 16 revealed a duplication of domain $\mathrm{A}$ in isolate 13 and domain $\mathrm{C}$ in isolate 16. Thus domain-encoding regions are not only deleted but also duplicated. Analysis of the different $M$. hominis strains, mainly isolates from the vagina presented here, reveals that the main form of the M. hominis adhesin in clinical isolates is represented by the originally described $50 \mathrm{kDa}$ variant (Christiansen, 1992; Feldmann et al., 1992; Henrich et al., 1993). This would suggest that this $50 \mathrm{kDa}$ variant represents the most stable form of expression for the p50 gene. We have observed that through point mutation, truncation and duplication, the p 50 gene can have a high degree of variability in which loss of one segment may be compensated for by recombination and duplication of another.

\section{ACKNOWLEDGEMENTS}

We thank Ellen Merten and Marzena Czarna for excellent technical assistance, Anja-Katrin Bielinsky for critically reading the manuscript and Karl Köhrer of the BMFZ in Duesseldorf for DNA sequencing. Our work was supported by the German Research Society (DFG; HA-409/3-1).

\section{REFERENCES}

Caruthers, M. H. (1982). New methods for synthesizing deoxyoligonucleotides. Genet Eng 4, 1-16.

Christiansen, G. (1992). Genetic variation in natural populations. In Mycoplasmas: Molecular Biology and Pathogenesis, pp. 561-571. Edited by J. Maniloff, R. N. McElhaney, L. R. Finch \& J. B. Baseman. Washington, DC: American Society for Microbiology.

Christiansen, G., Ladefoged, S., Hange, S., Birkelund, S. \& Andersen, H. (1990). Use of monoclonal antibodies for detection of gene and antigen variation in Mycoplasma hominis. Zentbl Bakteriol (Suppl.) 20, 535-545.

Feldmann, R.-C., Henrich, B., Kolb-Bachofen, V. \& Hadding, U. (1992). Decreased metabolism and viability of Mycoplasma bominis induced by monoclonal antibody-mediated agglutination. Infect Immun 60, 166-174.
Henrich, B., Feldmann, R.-C. \& Hadding, U. (1993). Cytoadhesins of Mycoplasma hominis. Infect Immun 61, 2945-2951.

Henrich, B., Kitzerow, A., Feldmann, R.-C., Schaal, H. \& Hadding, U. (1996). Repetitive elements of the Mycoplasma hominis adhesin P50 can be differentiated by monoclonal antibodies. Infect Immun 64, 4027-4034.

Higgins, D. G. \& Sharp, P. M. (1989). Fast and sensitive multiple sequence alignments on a microcomputer. Comput Appl Biosci 5, 151-153.

Krause, D. C. \& Taylor-Robinson, D. (1992). Mycoplasmas which infect humans. In Mycoplasmas: Molecular Biology and Pathogenesis, pp. 417-444. Edited by J. Maniloff, R. N. McElhaney, L. R. Finch \& J. B. Baseman. Washington, DC: American Society for Microbiology.

Luneberg, E., Kamla, V., Hadding, U. \& Frosch, M. (1991). Sequence and expression in Escherichia coli of a Mycoplasma bominis gene encoding elongation factor Tu. Gene 102, 123-127.

Mardh, P., Moller, B. R. \& McCormarck, W. M. (1983). M. hominis: a human pathogen. Sex Transm Dis 10, 4.

Olson, L. D., Shane, S. W., Karpas, A. A., Cunningham, T. M., Probst, P. S. \& Barile, M. F. (1991a). Monoclonal antibodies to surface antigens of a pathogenic Mycoplasma hominis strain. Infect Immun 59, 1683-1689.

Olson, L. D., Renshaw, C. A., Shane, S. W. \& Barile, M. F. (1991b). Successive synovial Mycoplasma hominis isolates exhibit antigenic variation. Infect Immun 59, 3327-3329.

Rosengarten, R. \& Wise, K. (1990). Phenotypic switching in mycoplasmas: phase variation of diverse surface lipoproteins. Science 247, 315-318.

Rosengarten, R. \& Wise, K. (1991). The $v / p$ system of $M$. byorhinis: combinatorial expression of distinct size variant lipoproteins generating high-frequency surface antigenic variation. J Bacteriol 173, 4782-4793.

Saito, N. \& Nei, M. (1987). The neighbor-joining method: a new method for reconstructing phylogenetic trees. Mol Biol Evol 4, 406-425.

Sambrook, J., Fritsch, E. F. \& Maniatis, T. (1989). Molecular Cloning: a Laboratory Manual, 2nd edn. Cold Spring Harbor, NY : Cold Spring Harbor Laboratory.

Sanger, F., Nicklen, S. \& Coulson, A. R. (1977). DNA sequencing with chain-terminating inhibitors. Proc Natl Acad Sci USA 74, 5436-5467.

Southern, E. M. (1975). Detection of specific sequences among DNA fragments separated by gel electrophoresis. $J$ Mol Biol $\mathbf{9 8 ,}$ 503-517.

Wise, K. S., Yogev, D. \& Rosengarten, R. (1992). Antigenic variation. In Mycoplasmas: Molecular Biology and Pathogenesis, pp. 473-489. Edited by J. Maniloff, R. N. McElhaney, L. R. Finch \& J. B. Baseman. Washington, DC: American Society for Microbiology.

Zhang, Q. \& Wise, K. (1996). Molecular basis of size and antigenic variation of a Mycoplasma hominis adhesin encoded by divergent vaa genes. Infect Immun 64, 2737-2744.

Zhang, Q. \& Wise, K. (1997). Localized reversible frameshift mutation in an adhesin gene confers a phase-variable adherence phenotype in mycoplasma. Mol Microbiol 25, 859-869.

Received 9 April 1998; revised 1 July 1998; accepted 9 July 1998. 